\title{
Speaking Skills Development through Communicative Language Teaching Techniques
}

\author{
Juan Carlos Silva-Valencia ${ }^{1}$, Wilma Villacís-Villacís ${ }^{1}$, Cynthia Hidalgo- \\ Camacho $^{2}$ \\ ${ }^{1}$ Language Center /Universidad Técnica de Ambato, Ecuador \\ ${ }^{2}$ Faculty of Philosophy, Letters and Educational Sciences / University of Cuenca, Ecuador
}

\begin{abstract}
.
This paper aims to analyze the impact communicative language teaching techniques have on the development of speaking skills in high school students. This research was carried out with the participation of 12 English teachers and 234 students. The data collection was done through the application of a survey. This instrument included 10 questions and it was validated by three experts. The purpose of the survey was to gather information that enable to have a close panorama of the two variables in the English classrooms. The results were thoughtfully analyzed and methodically tabulated. The Student's T-test was used to verify the established hypothesis, and the results indicated that communicative language teaching techniques have a positive impact on the development of English as a Foreign Language (EFL) speaking skills. Furthermore, the findings led to conclude that most students agree that they learn English best through interactive activities because they provide students with opportunities to interact using the target language. As part of the research, 20 communicative techniques were implemented, proving to promote engagement and effective oral production in the classroom.
\end{abstract}

Keywords: CLT; EFL; ESL; oral production, secondary education

\section{Introduction}

The theory of language in the form of communication known as Communicative Language Teaching (CLT) has caused a change in language learning, (Richards and Rodgers, as cited in Haryani \& Ainur, 2020). It was believed that the mastery of grammatical competence was the core element in language learning, which was viewed as a process of mechanical habit, but in recent years learning a language has focused on the communicative competence (Richards, 2006). In the same sense, Hymes (cited in Dos Santos, 2020) points out the importance of communicative competence. This author explains that this term refers to what a learner needs to know to successfully use a target language in a given language group.

Richards (2006) states that with the implementation of Communicative Language Teaching, teachers and learners have new roles in the classroom. They now plan activities which are characterized by interaction and collaboration. These two characteristics make learning a foreign or second language easier. For instance, the majority of people are studying English, which is also known as the 'Lingua Franca' or the global language. Mastering English has changed the way people interact in various fields (Xue \& Zuo, 
2013). In fact, English has been acknowledged as the global language and millions of people speak it, as a second or foreign language (Crystal, 2003).

Learning a lingua franca requires a proper methodology. Communicative Language Teaching has resulted to be efficient to teach and learn a language. Haryani and Ainur (2020) state that the CLT approach lets students have a better achievement in speaking in English. It promotes interaction and is the most recommended methods in EFL classes worldwide.

In Ecuador, for instance, the Ministry of Education (2014) in the National English Curriculum Guidelines acknowledges that the Communicative Approach is currently the most recognized, accepted norm in the field of language teaching and learning globally, since CLT comprises a theoretically well-informed set of principles. Therefore, the implementation of this approach is highly recommended in all levels of language instruction. In spite of this ministerial recommendation, the CLT approach is not being used by all teachers in Ecuador.

The focus of this study is the use of the communicative approach to enhance the teaching practice, and therefore deter the application of traditional approaches in the English language teaching. Learning a foreign language such as English is seen by many people as a difficult task. Most speakers of other languages point out the complexity of speaking in English. Paakki (2013) indicated that Finnish and Japanese learners asserted that the difficulty of speaking English is due numerous reasons. For example, previously there was great emphasis on grammar and theory, but practice, interaction and communication were neglected. In addition, the learners' oral performance was affected negatively due to the scarce language exposure and practice. Another factor that prevented learners from speaking English was the fear of making mistakes.

Likewise, the variety of accents constituted a drawback because learners were not able to grasp the language they heard in those settings. As a result of this, the students' oral production was inadequate. It can be said that speaking skills are challenging due to the aforementioned reasons.

Ecuadorian learners also face the obstacles described by Paakki while they try to develop their oral skills. Several teachers use ineffective ways to make students develop accurate oral production. Therefore, learners fail to learn the language. In addition to that, students lack enough practice to enhance their speaking skills.

Furthermore, another factor that has a negative impact on learners is the amount of focus on English language patterns. Al-Nammari, James and Ramachandran (as cited in Dong, 2016) argue that teachers regularly try to deliver their English knowledge and grammar structures while learners remain seated trying to internalize the shared information. Language forms are the core component. In other words, there is no focus on language use and interaction patterns. Hence, students' communicative competence is ineffective. Learners use their memory to recall the language forms rather than to communicate fluently.

There is evidence that EFL learners hardly accomplish the level of the expected fluency and accuracy. To improve this, activities to promote communication should be 
devised and implemented in the classroom. Pourhossein (2014) declares that EFL classrooms are facing a methodological change because interactive activities are being proposed. Learners develop the ability to use the language to communicate fluently. The same author further asserts that educators ought to motivate students to use the target language with their peers, allowing them to have a reduction in the amount of teacher talking time. Providing students with communicative activities is a must in every lesson to promote the meaningful use of language. Acknowledging all that was noted above, this study intended to analyze the influence communicative language teaching techniques have on the development of speaking skills.

\section{Body of paper}

Constructivism encourages students to build up their own knowledge, ideas and learning situations. Communicative language teaching and the social interactionalist focus on interaction among students in the class. Vygotsky (as cited in Rublik, 2017) stated that for students to acquire the target language, it is necessary for them to interact with their peers and teacher. In fact, without interaction, it would be very difficult to develop speaking skills and communicative competences (Yu, 2008).

There are many ways to foster oral production in the EFL classroom. One of them is proposing group work and pair work activities, while minimizing teacher talking time (Nunan, 2015). Interacting in this type of activities also provides students with the opportunity to take part in genuine conversations. Another example of an activity that could be used to promote communication in the classroom is role-playing, which offers the opportunity to use the target language to practice real life circumstances, according to the same author. In agreement, Chen-jun (as cited in Aliakbari \& Jamalvandi, 2010) defines Roleplays as one of the key means of oral production about real-life situations. Thornbury (2005) similarly highlights its versatility and practicality, and Larsen (2000) mentions the importance of this technique to present different social contexts and roles.

Simulations are also mentioned by Nunan. This technique offers students the opportunity to interact with others, responding to problems with their own roles, which is the main difference with role-playing. As Thornbury (2005) points out, learners take part in simulated activities as themselves, which involves improvisational realism. Lyu (2006) mentions that simulations are possible because learners are given functional parts such as representations for age, sex, among others Nunan also suggests Jigsaw activities. They are information gap activities that need to be completed with other person's information. Jigsaw activities can focus on writing, listening, reading, and most importantly, speaking. These activities are student-centered and, as Richards (2006) mentions, they allow students to communicate expressively.

Debates are also an alternative. Zare and Othman (2013) affirm that debates enhance speaking skills, while developing critical thinking skills. Alasmari and Salahuddin (2013) accentuate the fact that debating develops oral skills practice in real-life contexts, as well as important sub skills. All that, being achieved in either a formal or informal setting, depending on the topic chosen for the debate (Claxton, 2008). 
Mingles, as well, are effective techniques to foster communication in the classroom. Houston (2012) points out that speaking practice through mingles gives students the opportunity to express their thoughts individually. Borzova (2014) describes this activity as an informal speaking technique which promotes oral interaction and note-taking of the most important details of the information shared, before moving on to the next classmate. The techniques described are undoubtedly useful to promote the development of oral skills in the EFL classroom; however, the process of speaking a foreign language is rather complex and involves a process, as explained by Thornbury (2005).

Utterance is the key to speaking. Joining utterances or words require an appropriate use of syntax for the speaker to transmit their ideas well. This author defines English utterances as the combination of a topic and a comment. What we are talking about is the topic. Thornbury (2005) asserts that this information has already been mentioned. The comment, on the other hand, refers to all the details mentioned about the topic. Then, the comment normally is new information. This author also reveals that it is necessary to have grammatical parts such as articles, suffixes, auxiliary verbs, among others, for words to stand together.

Pronunciation takes place along with an appropriate stress and intonation during the formulation phase. According to Thornbury (2005) every person produces approximately ten thousand words everyday as part of their daily life; and coherent speech occurs when words are systematically produced one after the other.

Farouk (2014) highlights that speech production happens inside the vocal zone, involving several organs found inside the mouth and the throat which work together to produce speech sounds. Lungs, as well are involved in speech production since they need to be be filled of air for words to be produced. Clarity, pronunciation, intonation, volume, among others can be affected when an articulation organ is not working well.

Accuracy refers to appropriate language use in terms of grammar. It involves using the language for writing, or for speaking (Rishi, 2014). Sheppard (2015) adds that accuracy focuses on the use of proper vocabulary and grammar in order to convey meaning clearly.

Fluency, or the ability to use the language smoothly and in a natural way when speaking or writing it is also something that needs to be considered when speaking. A fluent speaker does not make unnecessary pauses or and can speak at a natural speed and maintain the natural flow of communication (Rishi, 2014).

Undoubtedly, communicative competence involves speaking skills. As it was mentioned by Farooq (2015), Hymes introduced the concept in the CLT method in the early 1970s. He believed that knowledge of a language and the skills to use it made a speaker communicatively competent. Additionally, Richards and Platt (as cited in Farooq, 2015) claim that CLT enhances the Communicative Competence development.

Larsari (2011) adds that unless there is enough exposure to the target language, it is difficult to develop Communicative Competence. Campbell (2004) posits that if learners do not have the appropriate access to the target language, the desired learning outcomes might 
not be accomplished. As Campbell proposes, EFL teachers are the ones to find the appropriate techniques to help students develop Communicative Competence.

Canale and Swain (as cited in Alami, 2014) suggest that sufficient acquisition of the four components of the Communicative Competence is needed. These competences are: the linguistic competence, which deals with the knowledge of language code; the sociolinguistic competence, which addresses the appropriate use of vocabulary, register, formality, and style of language, depending on the sociocultural situation or context the learners are dealing with; the discourse competence, concerned with the ability to divide language structures into different types of consistent written texts or oral exposition; and finally the strategic competence, that deals with the knowledge of both: verbal and non-verbal communication strategies, which improve efficiency of communication.

In addition to communicative competence and the key terms concerning speaking skills previously discussed, it is equally important to refer to the several speech conditions which make speaking either a complex or a simple process that also involves three different factors.

The cognitive factors refer to the fact that the student is familiar with the topic, the speakers and processing demands. The affective factors, on the other hand, are related to the feelings learners may experience at the moment of speaking (Krashen, 1982). He categorizes these factors into three groups: motivation, self-confidence, and anxiety. Finally, the performance factors describe the way students respond at the moment of speaking. There are several factors that affect students' performance. These entail time pressure, planning, and the amount of support given to the speaker (Nation \& Newton, 2009).

\section{Methods}

This research had both a qualitative and quantitative approach and pursued the understanding of a social phenomenon and had a systematic observation, which led to assume a dynamic existence. Furthermore, the contents regarding the problem were explained in detail, which made it a descriptive investigation. This study is also quantitative since the information gathered was systematically examined using numerical, mathematical and statistical procedures, which was later statistically tabulated. The Student T-test approach was applied to do the statistical analysis and prove the alternative hypothesis. Similarly, this study analyzed a variety of approaches, paradigms, theories, and principles of several authors whose studies and experiments relate to the contents of this research problem. 234 junior year high school students, and 12 EFL teachers from Ambato High School, located in Ambato, a city of the Andean region of Ecuador in South America constituted the sample. They were all surveyed with questionnaire which entailed 10 questions regarding the use of communicative activities in their English lessons.

\section{Results and Discussion}

* Results shown in this paper are part of an academic research linked to a thesis project.

After gathering the information, the alternative hypothesis, that communicative language teaching techniques improve speaking skills in high school students, was verified. Table 1 shows that the distribution under the null hypothesis of the variable $t$ was a Student's t-test with 14 degrees of freedom. As it can be seen, the ' $p$ ' value or level of bilateral significance is 
smaller than or equal to $a(0,05)$. Subsequently, the null hypothesis $\left(\mathrm{H}_{0}\right)$ is rejected, and the alternative hypothesis $\left(\mathrm{H}_{1}\right)$ is accepted.

Table 1. Test T Comparison between students' and teachers' answers

\begin{tabular}{|c|c|c|c|c|}
\hline \multicolumn{5}{|l|}{ Group Statistics } \\
\hline QUESTIONS & TYPE & $\mathbf{N}$ & $\begin{array}{l}\text { Averag } \\
\text { e }\end{array}$ & $\begin{array}{c}\text { Standard } \\
\text { Deviation }\end{array}$ \\
\hline \multirow{2}{*}{$\begin{array}{l}\text { 1. I consider that the oral communication in } \\
\text { English is the most effective and frequent manner to } \\
\text { communicate in real life situations. }\end{array}$} & Students & 234 & - & 0,995 \\
\hline & Teachers & 12 & 4,58 & 0,515 \\
\hline \multirow{2}{*}{$\begin{array}{l}\text { 2. I learn English best through interaction tasks } \\
\text { either in pairs or in groups (role plays, } \\
\text { conversations, dialogues). } \\
\text { Students learn English best through interaction } \\
\text { tasks either in pairs or in groups (role plays, } \\
\text { conversations, dialogues). }\end{array}$} & Students & 234 & 4,10 & 0,895 \\
\hline & Teachers & 12 & 4,50 & 0,522 \\
\hline \multirow{2}{*}{$\begin{array}{l}\text { 3. My teacher does activities to practice oral } \\
\text { communication in English. } \\
\text { I provide students with activities to practice oral } \\
\text { communication in English. }\end{array}$} & Students & 234 & 2,94 & 1,057 \\
\hline & Teachers & 12 & 4,00 & 0,739 \\
\hline \multirow{2}{*}{$\begin{array}{l}\text { 4. I like the activities that my teacher develops } \\
\text { in class to promote oral communication in English. } \\
\text { My students like the activities developed in } \\
\text { class to promote oral communication in English. }\end{array}$} & Students & 234 & 3,21 & 0,992 \\
\hline & Teachers & 12 & 4,08 & 0,669 \\
\hline \multirow{2}{*}{$\begin{array}{l}\text { 5. The activities that are done in class mostly } \\
\text { permit me to develop oral communication in } \\
\text { English. } \\
\text { The activities that are done in class mostly allow } \\
\text { students to develop oral communication in English. }\end{array}$} & Students & 234 & 2,75 & 1,036 \\
\hline & Teachers & 12 & 3,75 & 0,866 \\
\hline \multirow{2}{*}{$\begin{array}{l}\text { 6. My teacher tells me what I did right or wrong } \\
\text { and what I have to improve based on my oral } \\
\text { performance in English. } \\
\text { I let students know what they need to improve } \\
\text { based on their oral performance in English. }\end{array}$} & Students & 234 & 2,98 & 1,068 \\
\hline & Teachers & 12 & 4,00 & 1,044 \\
\hline \multirow{2}{*}{$\begin{array}{l}\text { 7. The activities done in class mainly focus on } \\
\text { oral communication rather than grammatical } \\
\text { explanation. }\end{array}$} & Students & 234 & 2,80 & 0,993 \\
\hline & Teachers & 12 & 3,50 & 0,798 \\
\hline \multirow{2}{*}{$\begin{array}{l}\text { 8. I can understand and communicate in English } \\
\text { orally without much difficulty. } \\
\text { My students understand and communicate in } \\
\text { English orally without much difficulty. }\end{array}$} & Students & 234 & 2,93 & 1,058 \\
\hline & Teachers & 12 & 3,25 & 0,622 \\
\hline $\begin{array}{l}\text { 9. My teacher motivates me to speak and } \\
\text { communicate in English inside and outside the } \\
\text { classroom. }\end{array}$ & Students & 234 & 3,20 & 0,969 \\
\hline
\end{tabular}


3rd International Academic Conference on Education, Teaching \& Learning

I motivate my students to speak and communicate in English inside and outside the classroom.

10. We are given enough time, clear instructions and proper guidance to develop the interaction tasks.

Students are given enough time, clear instructions and proper guidance to develop the interaction tasks.

\begin{tabular}{|l|r|r|r|}
\hline Teachers & 12 & 3,83 & 0,718 \\
\hline Students & 234 & 3,58 & 0,896 \\
\hline Teachers & 12 & 4,50 & 0,674 \\
\hline Students & $\mathbf{2 3 4}$ & $\mathbf{3 , 2 0}$ & $\mathbf{0 , 8 2 6}$ \\
\hline Teachers & $\mathbf{1 2}$ & $\mathbf{4 , 0 0}$ & $\mathbf{0 , 6 0 3}$ \\
\hline
\end{tabular}

Source: Student and teacher survey

Created by: Researchers

Graph 1. Average questions 1 to 5

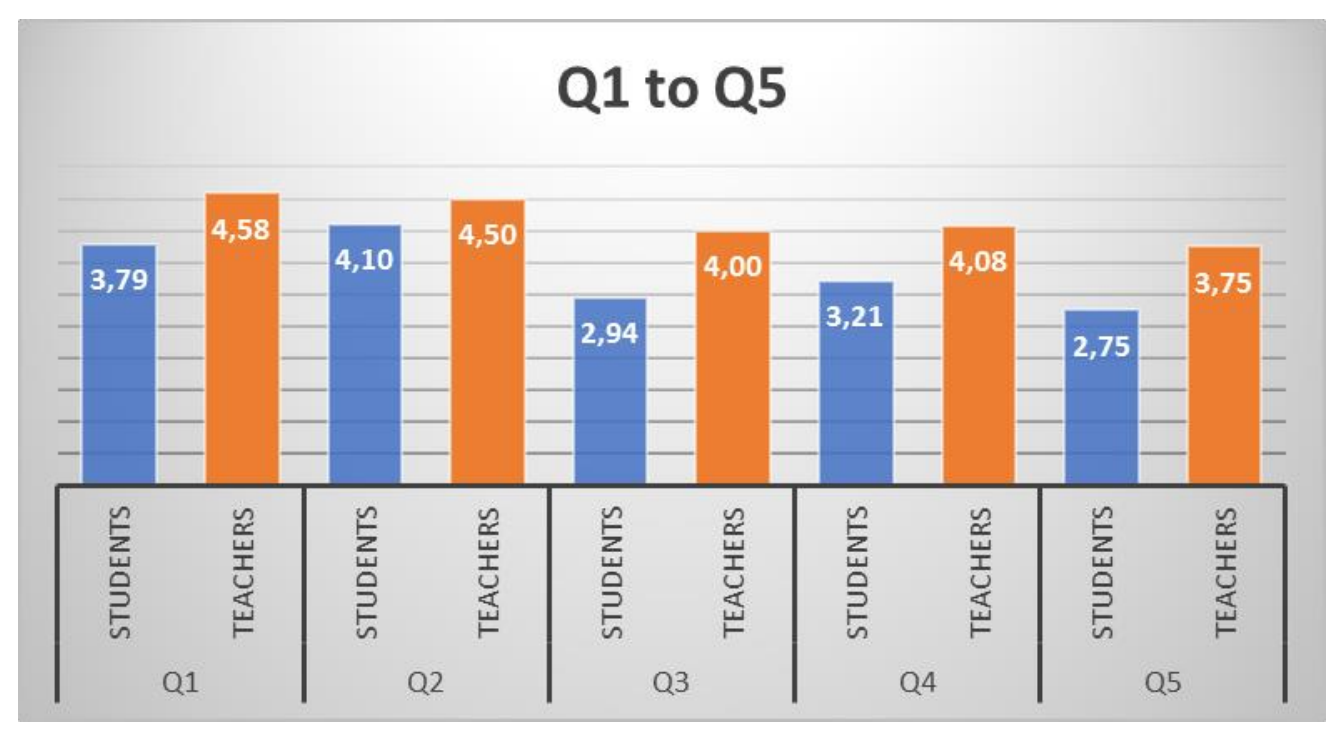

Source: Student and teacher survey

Created by: Researchers

Graph 2. Average questions 6 to 10 


\section{Q6 to Q10 and TOTAL}

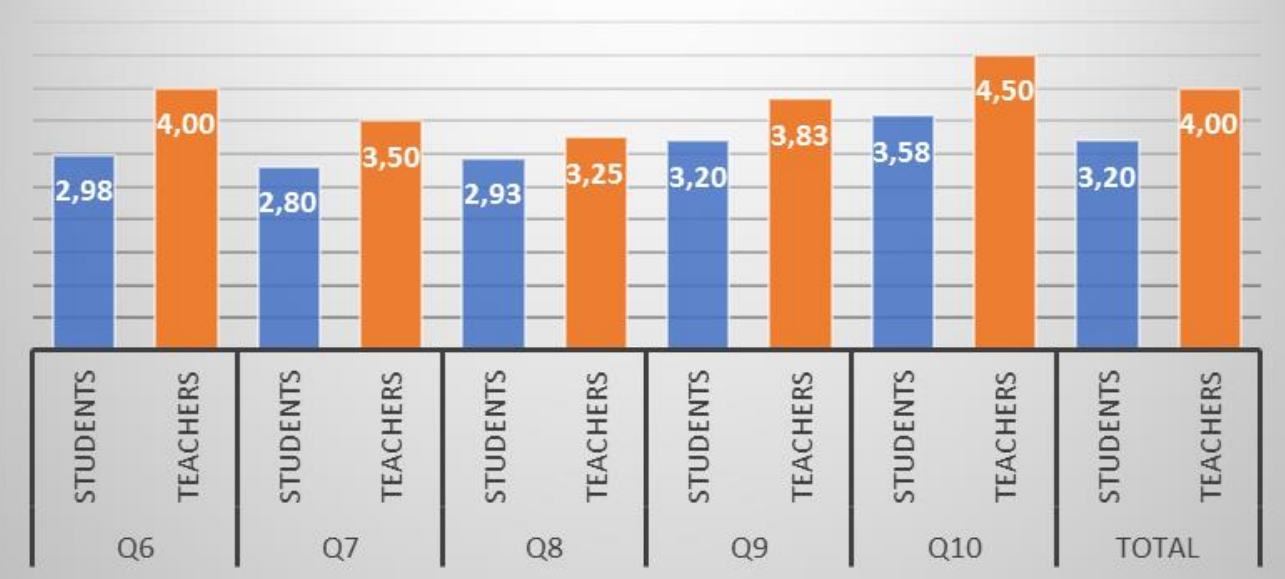

Source: Student and teacher survey

Created by: Researchers

The average response of the teacher was higher than the average of the student in each question. This means, the teacher has a better appreciation of the techniques used.

Table 3. Student's T-test: Summary of each question

\begin{tabular}{|c|c|c|c|c|}
\hline \multicolumn{5}{|c|}{ Group Statistics } \\
\hline QUESTIONS & TYPE & Average & $\begin{array}{l}\text { Bilateral } \\
\text { Signif. }\end{array}$ & Observation \\
\hline \multirow{2}{*}{ Question 1} & Students & 3,79 & \multirow{2}{*}{0,007} & \multirow{2}{*}{ Different } \\
\hline & Teachers & 4,58 & & \\
\hline \multirow{2}{*}{ Question 2} & Students & 4,10 & \multirow{2}{*}{0,125} & \multirow{2}{*}{ Similar } \\
\hline & Teachers & 4,50 & & \\
\hline \multirow{2}{*}{ Question 3} & Students & 2,94 & \multirow{2}{*}{0,001} & \multirow{2}{*}{ Different } \\
\hline & Teachers & 4,00 & & \\
\hline \multirow{2}{*}{ Question 4} & Students & 3,21 & \multirow{2}{*}{0,003} & \multirow{2}{*}{ Different } \\
\hline & Teachers & 4,08 & & \\
\hline \multirow{2}{*}{ Question 5} & Students & 2,75 & \multirow{2}{*}{0,001} & \multirow{2}{*}{ Different } \\
\hline & Teachers & 3,75 & & \\
\hline \multirow{2}{*}{ Question 6} & Students & 2,98 & \multirow{2}{*}{0,001} & \multirow{2}{*}{ Different } \\
\hline & Teachers & 4,00 & & \\
\hline \multirow{2}{*}{ Question 7} & Students & 2,80 & \multirow{2}{*}{0,017} & \multirow{2}{*}{ Different } \\
\hline & Teachers & 3,50 & & \\
\hline Question 8 & Students & 2,93 & 0,303 & Similar \\
\hline
\end{tabular}


3rd International Academic Conference on Education, Teaching \& Learning

\begin{tabular}{|c|c|c|c|c|}
\hline & Teachers & 3,25 & & \\
\hline \multirow[t]{2}{*}{ Question 9} & Students & 3,20 & \multirow{2}{*}{0,026} & \multirow{2}{*}{ Differen } \\
\hline & Teachers & 3,83 & & \\
\hline \multirow{2}{*}{ Question 10} & Students & 3,58 & \multirow{2}{*}{0,001} & \multirow{2}{*}{ Different } \\
\hline & Teachers & 4,50 & & \\
\hline \multirow{2}{*}{ TOTAL } & Students & 3,20 & \multirow{2}{*}{0,001} & \multirow{2}{*}{ Differen } \\
\hline & Teachers & 4,00 & & \\
\hline
\end{tabular}

Source: Student and teacher survey

Created by: Researchers

Figure 1. Normal distribution Density Curve

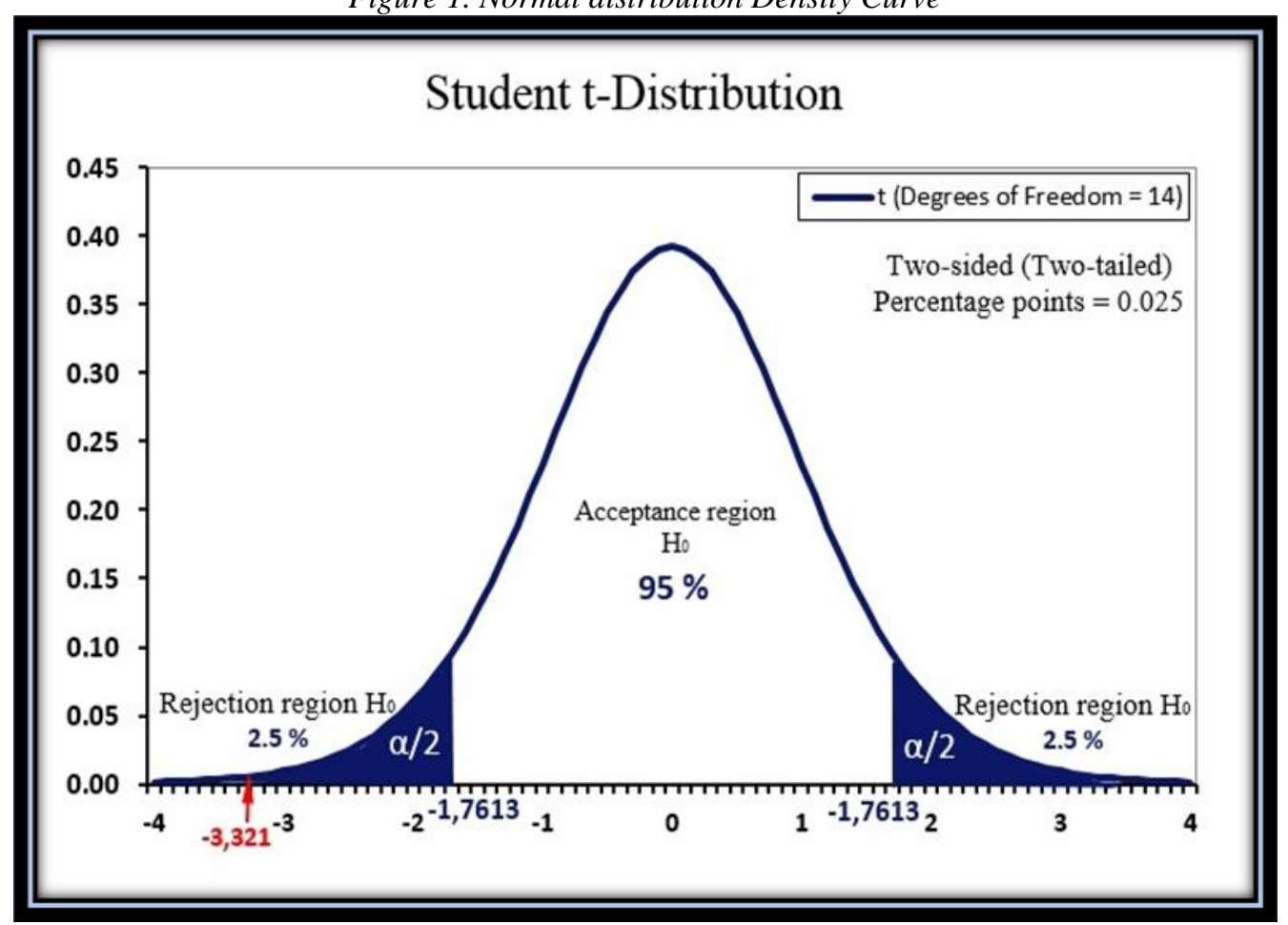

Source: Student and teacher survey

Created by: Researchers

\subsection{1}

According to the values: 14 degrees of freedom, 0.05 of level of significance, $p=0,001<a$ $=0,05$, given that the $t$ calculated: $-3,321$ is $<-1,7613$ from the $t$ distribution table, which demonstrates that the total average calculated from the students responses was different from the one obtained for teachers. 


\section{Conclusion}

One of the most important findings of this study is the usefulness of communicative language teaching techniques, although their use is not common in high school EFL classes. This led to the implementation of 20 communicative techniques which aimed to improve speaking skills development.

It was also made visible to the researchers that there is a significant number of students who struggle to communicate in the target language, basically because the activities proposed in the classrooms usually emphasize grammar. For that reason, this work on the development of speaking skills sought to provide teachers and students with communicative teaching techniques that could be used in EFL classrooms, taking into account the characteristics of high school learners who normally are not confident enough to speak English in their EFL classes. They are afraid of making mistakes and failing to communicate efficiently and fluently.

The survey showed that most students consider that English is best learned through interactive activities, however, most EFL classes lack techniques that ensure oral interaction. Although some EFL teachers intend to foster English speaking in their classrooms, their students were not entirely engaged in the activities used before the intervention. Therefore, lesson plans and expected learning outcomes were revised to make sure that the proposed communicative techniques were efficiently being used to develop speaking skills.

\section{References}

Alasmari, A., \& Salahuddin, S. (2013). Using Debate in EFL Classes. English Language Teaching, 148.

Aliakbari, M., \& Jamalvandi, B. (2010). The Impact of 'Role Play' on Fostering EFL Learners' Speaking Ability: A Task-Based Approach. Pan-Pacific Association of Applied Linguistics, 20.

Borzova, E. (2014). Mingles in the Foreign Language Classroom. English Teaching Forum, 20.

Campbell, A. (2004). Using LiveJournal for Authentic Communication in EFL Classes. The Internet TESL Journal.

Claxton, N. (2008). Using Deliberative Techniques in the English as a Foreign Language Classroom. International debate education association, 61 .

Crystal, D. (2003). English as a Global Language. New York: Cambridge University Press.

Dos Santos, L. (2020). The Discussion of Communicative Language Teaching Approach in Language Classrooms. Journal of Education and e-learning Research, 104-109.

Dong, X. (2016). Research on the Teaching Methods of College English. Creative Education, 1233-1236. 
3rd International Academic Conference on Education, Teaching \& Learning

Farooq, M. U. (2015). Creating a Communicative Language Teaching Environment for Improving Students' Communicative Competence at EFL/EAP University Level. International Education Studies; 179.

Farouk, M. (2014). Speech Production and Perception. In M. Farouk, Application of Wavelets in Speech Processing (pp. 5-10). Springer.

Haryani, \& Ainur, A. (2020). A Collaboration Between Communicative Language Teaching (CLT), Audiolingual, and Community Language Learning (CLL) Approach in Teaching and Learning English at SMA 1 Singorojo Kendal. Journal of English Education and Teaching (JEET), 127-140.

Houston, H. (2012). Mastering the Mingle. International House Journal.

Krashen, S. (1982). Principles and Practice in Second Language Acquistion. California: Pergamon Press Inc.

Larsari, V. N. (2011). Learners' communicative competence in English as a foreign language (EFL). Journal of English and literature, 161.

Larsen, F. D. (2000). Techniques and Principles in Language Teaching. New York: Oxford University Press.

Lyu, Y. (2006). Simulations and second/foreign language learning: improving communication skills through simulations. Theses and Dissertations, 12.

Ministry of, E. (2014, August). National Curriculm Guidelines. Retrieved from http://educacion.gob.ec/wp-content/uploads/downloads/2014/09/01-National-CurriculumGuidelines-EFL-Agosto-2014.pdf

Nation, I. S., \& Newton, J. (2009). Teaching ESL/EFL Listening and Speaking. ESL \& Applied Linguistics Professional Series. New York: Routledge.

Nunan, D. (2015). Teaching English To Speakers Of Other Languages An Introduction. New York: Routledge.

Paakki, H. (2013, October). Difficulties in Speaking English and Perceptions of Accents: A Comparative Study of Finnish and Japanese Adult Learners of English. Master's thesis. School of Humanities.

Pourhossein, A. (2014). Classroom Interaction and Development Speaking Skill. Department of English Language, Science and Research Barances.

Richards, J. C. (2006). Communicative Language Teaching Today. New York: Cambridge Univesity Press.

Rishi, S. (2014). Accuracy Vs Fluency in English Classroom. New Man International Journal of Multidisciplinary Studies, 55-58.

Rublik, N. (2017). Language Acquisition and Cultural Mediation: Vygotskian Theory. Asican Pacific Journal of Contemporary Education and Communication Technology, 334-345. 
Sheppard, R. (2015, October 12). Fuency and Accuracy Activities: Striking a Balance. Retrieved from http://blog.tesol.org/fluency-and-accuracy-activities-striking-a-balance/

Silva Valencia, J. C. (2018). Communicative language teaching techniques for enriching the speaking skill in high school students (Master's thesis, Universidad Técnica de Ambato. Dirección de Posgrado. Maestría en Enseñanza del Idioma Inglés como Lengua Extranjera).

Thornbury, S. (2005). How To Teach Speaking. Harlow: Pearson.

Vibulphol, J. (2016). Students' Motivation and Learning and Teachers' Motivational Strategies in English Classrooms in Thailand. English Language Teaching.

Xue, J., \& Zuo, W. (2013). English Dominance and Its Influence on International Communication. Theory and Practice in Language Studies, 2262-2266.

Yu, R. (2008). Interaction in EFL Classes. Asian Social Science, 48.

Zare, P., \& Othman, M. (2013). Classroom Debate as a Systematic Teaching/Learning Approach. World Applied Sciences Journal, 1506 